\title{
Emsian-Eifelian lingulate brachiopods from the Daleje-Třebotov Formation (Třebotov and Suchomasty limestones) and the Choteč Formation (Choteč and Acanthopyge limestones) from the Prague Basin; the Czech Republic
}

\author{
MICHAL MERGL \& STANISLAVA VODRÁŽKOVÁ
}

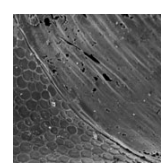

\begin{abstract}
Taxonomic composition and stratigraphic distribution of lingulate brachiopod taxa around the Emsian/Eifelian boundary of the Prague Basin were examined. Twelve species have been determined and the presence of others is suggested. The prevalence of micromorphic biernatids, Havlicekion and Opsiconidion, in all the studied samples is significant. A mode of life for biernatids, especially from the genus Opsiconidion, is discussed. A new Devonian occurrence of the siphonotretid Orbaspina is recorded. Lingulate brachiopods do not display any significant change around the Emsian/Eifelian boundary or at the Basal Choteč Event (Middle Devonian, Eifelian, costatus Zone) and thus confirm the general uniformity of lingulate faunas in the Lower and early Middle Devonian. - Key words: Brachiopoda, Linguliformea, Biernatidae, Opsiconidion, Orbaspina, Emsian, Eifelian, Basal Choteč Event, Prague Basin.
\end{abstract}

\begin{abstract}
MERGL, M. \& VODRÁŽKOVÁ, S. 2012. Emsian-Eifelian lingulate brachiopods from the Daleje-Třebotov Formation (Třebotov and Suchomasty limestones) and the Choteč Formation (Choteč and Acanthopyge limestones) from the Prague Basin; the Czech Republic. Bulletin of Geosciences 87(2), 315-332 (11 figures). Czech Geological Survey, Prague, ISSN 1214-1119. Manuscript received July 7, 2011; accepted in revised form January 11, 2012; published online March 29, 2012; issued March 30, 2012.

Michal Mergl, Department of Biology, Faculty of Education, University of West Bohemia in Plzeň, Klatovská 51, 30619 Plzeň, Czech Republic; mmergl@kbi.zcu.cz・Stanislava Vodrážková, Czech Geological Survey, P.O.B. 85, 11821 Prague 1, Czech Republic, and GeoZentrum Nordbayern, Fachgruppe Paläoumwelt, Friedrich-Alexander-Universität Erlangen-Nürnberg, Loewenichstr.28, Erlangen, Germany; stana.vodrazkova@seznam.cz.
\end{abstract}

\begin{abstract}
Although highly fragmentary in preservation, a moderately diverse fauna of organophosphatic brachiopods has recently been found together with conodonts around the Emsian/Eifelian boundary in the Prague Basin. Only a few linguliformean taxa had been reported from this interval by previous authors (Barrande 1879, Mergl 2001a). With a few exceptions, modern descriptions (Mergl 2001a) are based on specimens collected from the Prastav quarry in Praha - Holyně, the reference section for the Lower/Middle Devonian boundary. The aim of this paper is to produce a detailed description of the Emsian-Eifelian lingulate brachiopods and improve the correlation of the conodont and linguliformean brachiopod distributions based on the new data gathered from several sections in the Prague Basin.

Investigation of the autecology of biernatids is difficult and only little has become known since the first discussion by Cocks (1979). Another goal of this paper is therefore to shed more light on biernatids ecology based on new distributional observations.
\end{abstract}

\section{Geological setting}

The lingulate brachiopod faunas presented herein were sampled from the Třebotov and Suchomasty limestones (Daleje-Třebotov Formation, Lower/Middle Devonian, upper Emsian-Eifelian) and Choteč and Acanthopyge limestones (Choteč Formation, Middle Devonian, Eifelian). The following sections were sampled (Fig. 1): Praha - Barrandov (road cut), Praha - Holyně (Prastav quarry), Choteč (Na Škrábku quarry), Chýnice (Jelínek mill quarry), Karlštejn (U Němců section), Suchomasty (Červený quarry). For the stratigraphy of the sections studied see Berkyová (2009) and references therein.

The Třebotov Limestone unit was defined by Svoboda \& Prantl (1947) and redefined by Chlupáč (1957). It is represented by light, medium to thin-bedded, bioturbated, skeletal wackestones and packstones with abundant dacryoconarid tentaculites (mostly styliolinids), ostracods, nautiloids, ammonoids, trilobites, brachiopods, 


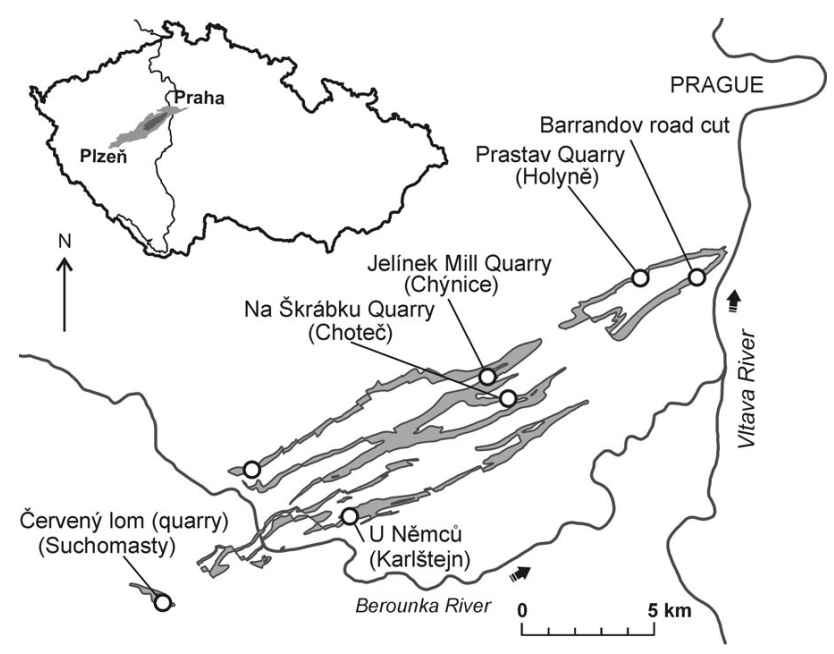

Figure 1. Schematic map showing the location of the Prague Basin in the Czech Republic and the distribution of the Daleje-Třebotov and Choteč formations with positions of the sampled sections. Drawing of Daleje-Třebotov and Choteč formations distribution is based on geological maps 1:25,000 published by Czech Geological Survey. Slightly modified after Berkyová (2009).
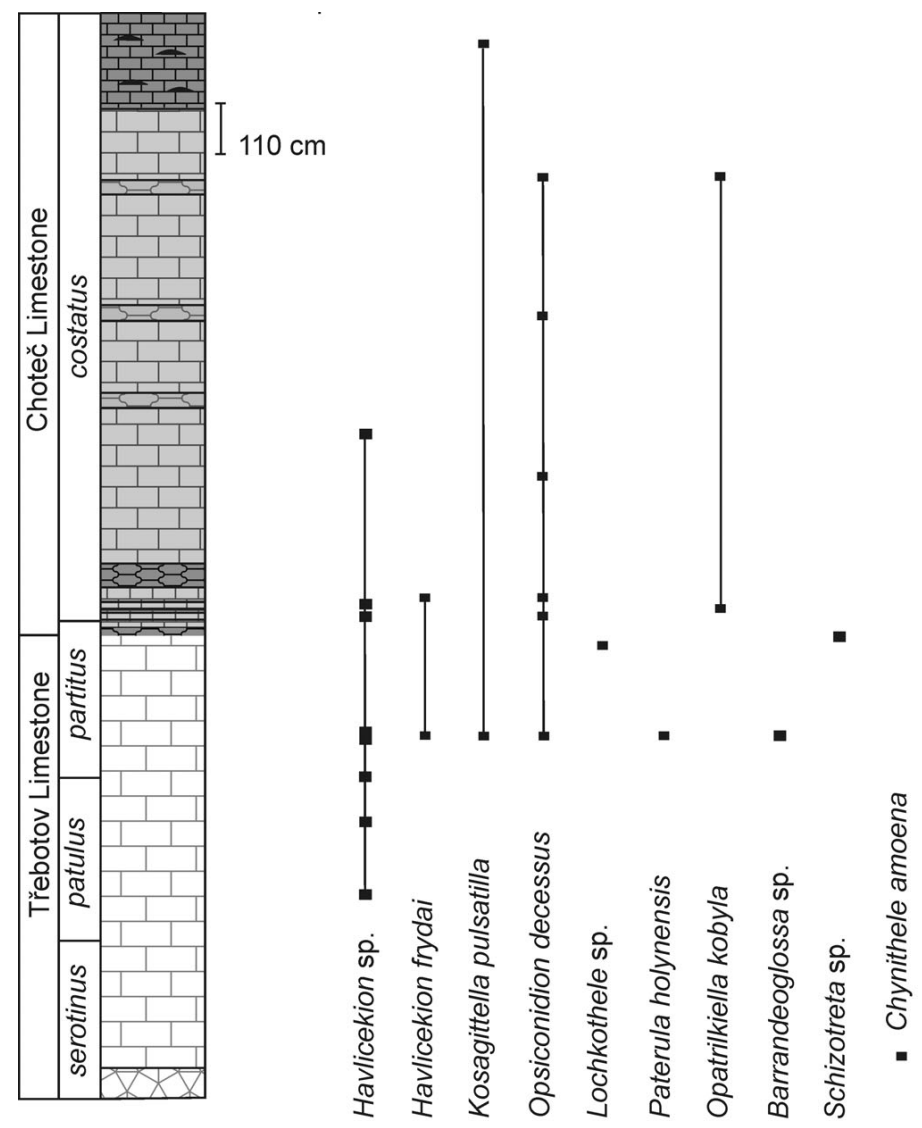

echinoderms, and subordinate bivalves. The fragmentary preservation of diverse benthic invertebrates, well preserved plankton, the intense bioturbation, and the lack of sedimentary features indicating current activity suggests relatively deep, well oxygenated, soft bottom sea floor with high biological activity below the storm wave base (see also Chlupáč 1977, 1983). A different environment was established in the shallow water Koněprusy area, where the Suchomasty Limestone, the stratigraphic equivalent of the Třebotov Limestone, was deposited. The depositional environment of the Suchomasty Limestone was interpreted by Havlíček \& Kukal (1990, p. 111) as "shallow water, temporarily agitated, temporarily quiet", distant from a high-energy platform margin, with an abundant benthic fauna, especially rich in trilobites, brachiopods and crinoids. A profound basin-wide lithologic change from light, bioturbated skeletal wackstones to dark peloidal grainstones indicates the boundary between the Třebotov and Choteč limestones. The Choteč Limestone unit, defined by Svoboda \& Prantl (1947) and redefined by Chlupáč (1957), reflects in its development and fossil content environmental stress linked to the important

Figure 2. Simplified lithological column of the Na Škrábku quarry (Choteč) with brachiopod taxa ranges. The base of the costatus Zone is drawn according to the occurrence of P. sp. aff. P. trigonicus and Nowakia (Dmitriella) sulcata sulcata. For stratigraphic ranges of conodonts see Berkyová (2009). 
eustatic transgressive event, known as the Basal Choteč Event (e.g., Chlupáč \& Kukal 1986, 1988; Elrick et al. 2009; Koptíková 2010; Vodrážková et al. accepted for publication). The Choteč Formation consists of calciturbidites (dark, graded peloidal grainstones with crinoids and crinoidal grainstones with peloids alternating with dark burrowed/laminated lime-mudstones and burrowed/bioturbated light grey skeletal wackestones). Various types of peloids, micritized grains, accumulations of calcispheres and prasinophytes at specific levels represent characteristic features of this unit and are regarded as a result of environmental changes, e.g. higher nutrient load, linked to the Basal Choteč Event (Berkyová \& Munnecke 2010). Apart from this, the Choteč limestone is characterised by an impoverished fossil content (see also Chlupáč et al. 1979; Chlupáč \& Kukal 1986, 1988). Dacryoconarid tentaculites (styliolinids), nautiloid remains, trilobite exoskeletons and small unidentifiable skeletal debris represent the most common constituents. For the stratigraphic distribution of brachiopod taxa studied along with conodont zonation see Figs 2-6.

\section{Methods}

The extraction of phosphatic brachiopod shells from limestones followed a standard technique. This comprised dissolution of limestone in diluted acetic acid (6\%), sieving and drying the residues, and handpicking the specimens under a binocular microscope. Separation in heavy liquid (sodium polytungstate) was carried out. SEM documentation was carried out at the Institute of Geology and Palaeontology, Charles University in Prague using a JEOL JSM-6380.

\section{Repository}

All specimens are housed in the palaeontological collections of the Czech Geological Survey, Prague (SB6-SB43).

\section{Systematic section}

Order Lingulida Waagen, 1885

Superfamily Linguloidea Menke, 1828

Family Obolidae King, 1846

Subfamily Glossellinae Cooper, 1956

\section{Genus Barrandeoglossa Mergl, 2001a}

Type species. - Lingula fissurata Barrande, 1879; Motol Formation, Wenlock, Silurian; Prague Basin, the Czech Republic.

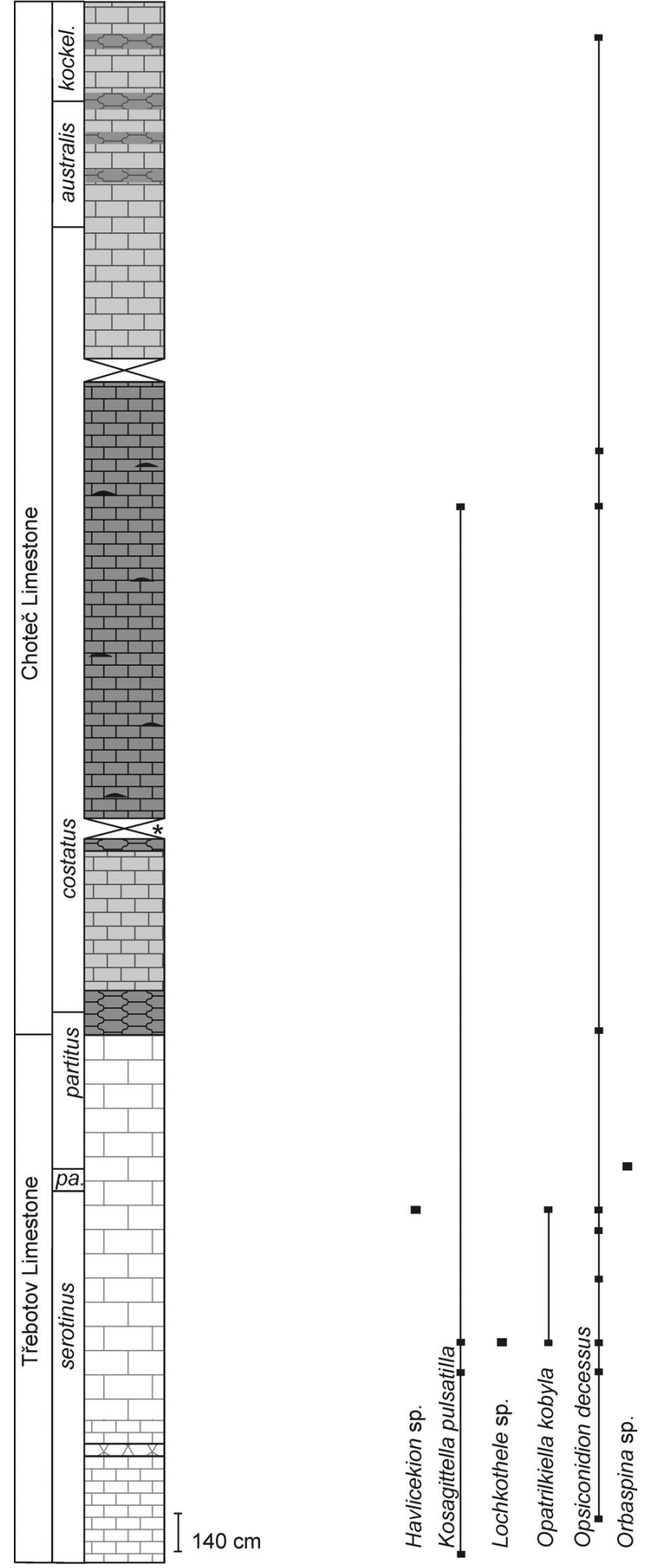

Figure 3. Simplified lithological column of the Jelínek mill quarry (Chýnice) with brachiopod taxa ranges. See legend in Fig. 2. For stratigraphic ranges of conodonts see Berkyová (2009). * not in scale, estimation of the covered interval is $c a 6 \mathrm{~m}$. 


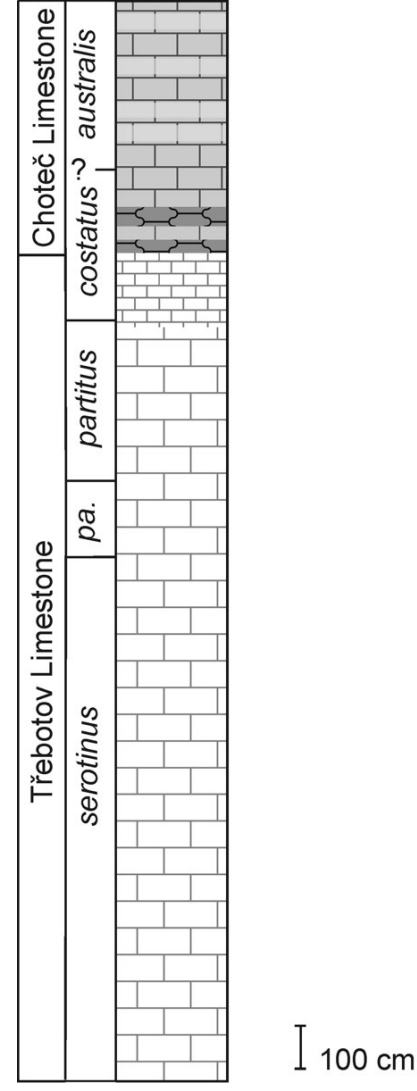

Figure 4. Simplified lithological column of the Barrandov road cut section (Praha - Barrandov) with brachiopod taxa ranges. The bases of the patulus and partitus zones were drawn according to data published by Zusková (1991). For stratigraphic ranges of conodonts see Berkyová (2009).

\section{Barrandeoglossa sp.}

Figure 7A

Material. - Two incomplete valves, one fragment.

Description. - One incomplete dorsal valve probably represents a juvenile shell. It is $1.8 \mathrm{~mm}$ wide and weakly convex in transverse profile. The valve bears a subcircular, smooth larval shell, $800 \mu \mathrm{m}$ long and $900 \mu \mathrm{m}$ wide. The larval shell is bordered posterolaterally by a very short swollen brim extending from the posterior margin. Posterior and lateral margins are evenly rounded. The surface of the post-larval shell bears weak concentric fila that are axially subdued.

Remarks. - The shell is similar to that of Barrandeoglossa perneri Mergl, 2001a from the Lochkov Formation (Monograptus uniformis Zone) in outline and in the swollen posterior margin. It is the youngest report of the genus so far recorded.

Occurrence. - Choteč (Na Škrábku quarry), Třebotov Limestone, partitus Zone.
Subfamily Obolinae King, 1846

\section{Genus Kosagittella Mergl, 2001a}

Type species. - Kosagittella clara Mergl, 2001a; Kopanina Formation, Ludlow, Silurian; Prague Basin, the Czech Republic.

\section{Kosagittella pulsatilla Mergl, 2008}

Figure 7B-D

2001a Kosagitella (?) lingua (Barrande, 1879) - Mergl, pp. 12, 13, pl. 3, figs 16-18.

2008 Kosagitella pulsatilla sp. nov. - Mergl, pp. 284-286, fig. 3A-Q.

Material. - Ten valves, mostly incomplete.

Description. - The shell is biconvex, elongate oval, fairly thick walled relative to the shell size, $1.6 \mathrm{~mm}$ long being the largest complete valve. The dorsal valve is elongate oval, $130 \%$ as long as wide in the single preserved complete shell, having a slightly pointed apex. The subcircular larval shell is about $400 \mu \mathrm{m}$ wide, with distinct sides, raised boundary and smooth surface. The sides and anterior margins are evenly rounded, with the anterior third of the shell regularly semicircular in outline. The maximum width is located anterior to the midlength of the shell. The valve is gently and evenly convex transversally and axially. The dorsal interior is unknown.

The ventral valve has an outline similar to the dorsal valve but having a more pointed apex. The subcircular larval shell is gently convex. The ventral pseudointerarea is orthocline, short, gently inclined posteroventrally, without distinct flexure lines. The pseudointerarea is divided by a short, broad and shallow pedicle groove, which continues on the posterior slope of the visceral area as a gently expanding groove. The anterior edge of the propareas forms a high undivided steep slope.

Ornamentation consists of weak growth fila, distinct posterolaterally, which weaken anteriorly and axially. Microornamentation of the early mature shell consists of deep, hemisphaerical $3 \mu \mathrm{m}$ sized evenly spaced pits.

Remarks. - Although rare and poorly preserved, the specimens can be unambiguously referred to Kosagittella pulsatilla Mergl, 2008, originally described from the Acanthopyge Limestone (Eifelian) of the Koněprusy area of the Prague Basin. The identity is also demonstrated by a characteristic pitted microornamentation of the post-larval shell (Fig. 7D) observed in all new specimens.

Occurrence. - Chýnice (Jelínek mill quarry), Třebotov and Choteč limestones, serotinus-costatus zones; Choteč 
(Na Škrábku quarry), Třebotov and Choteč limestones, partitus-?australis zones (the presence of the australis Zone is based on the occurrence of conodont taxa Polygnathus trigonicus Bischoff \& Ziegler, 1957 and P. pseudofoliatus Wittekindt, 1966); Suchomasty (Červený quarry), Acanthopyge Limestone, costatus Zone (zonal identification based on the occurrence of Polygnathus sp. aff. Polygnathus trigonicus Bischoff \& Ziegler, 1957 reported by Klapper et al. 1978).

\section{Family Paterulidae Cooper, 1956}

\section{Genus Paterula Barrande, 1879}

Type species. - Paterula bohemica Barrande, 1879; Vinice Formation, Sandbian, Ordovician; Prague Basin, the Czech Republic.

\section{Paterula holynensis Mergl, 2001a}

Figure $7 \mathrm{G}, \mathrm{K}$

2001a Paterula holynensis sp. n. - Mergl, pp. 18, 19, pl. 11, figs 9-13, pl. 12, figs 1-15.

Material. - One fragment.

Remarks. - The fragment shows distinctive microornamentation comprising rhomboidal pits on the post-larval shell (Fig. 7G) and can be referred to P. holynensis Mergl, 2001a. It is the first report of the genus from the Třebotov Limestone.

Occurrence. - Choteč (Na Škrábku quarry), Třebotov Limestone, partitus Zone.

Superfamily Discinoidea Gray, 1840

Family Discinidae Gray, 1840

\section{Genus Acrosaccus Willard, 1928}

Type species. - Acrosaccus shuleri Willard, 1928; Rich Valley Formation, Caradocian, Ordovician; Virginia, the USA.

\section{Acrosaccus sp.}

Figure $7 \mathrm{H}$, I

Material. - Four fragments, two from a ventral valve.

Description. - Small fragments of the thick-walled, low conical ventral valve showing a deep, spindle-shaped pedicle track with steeply sloping outer listrial plates.



Figure 5. Simplified lithological column of the Prastav quarry (Praha Holyně) with brachiopod taxa ranges. The bases of the serotinus and patulus zones are drawn according to data published by Klapper (1977). For stratigraphic ranges of conodonts see Berkyová (2009).

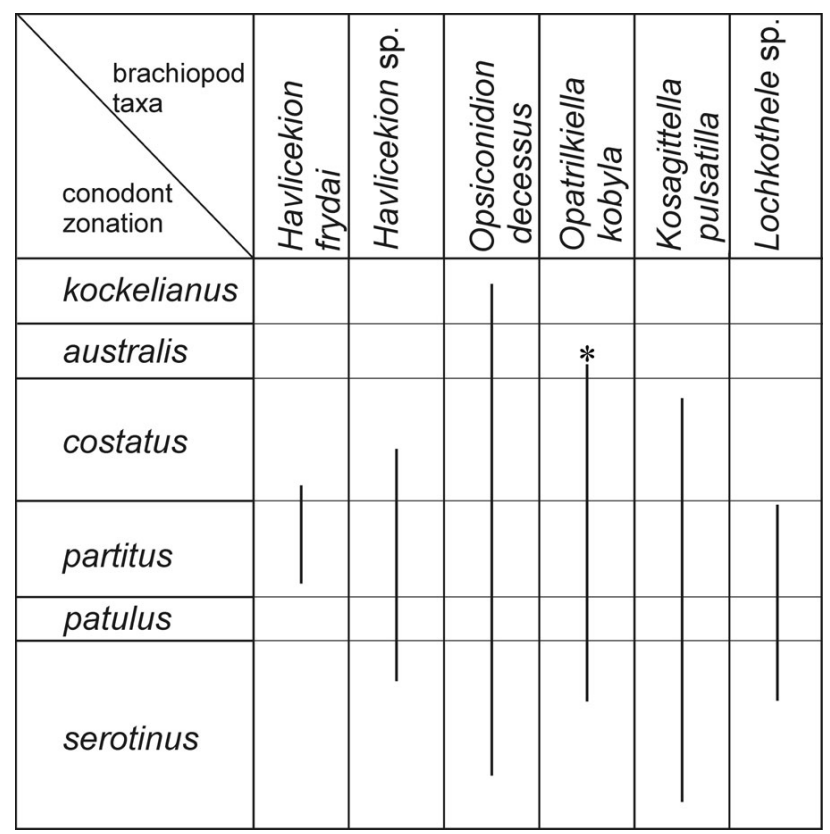

Figure 6. Stratigraphical ranges of the selected brachiopod taxa in the Prague Basin. * australis Zone is based of the occurrence of Polygnathus pseudofoliatus Wittekindt, 1966. 
Ornamentation consists of progressively coarser, tall concentric and somewhat irregular rugellae separated by broader interspaces. The rugellae cover the posterior and lateral slopes of the valve. The ornamentation of the anterior slope is unknown.

Remarks. - The material indicates the presence of a thickwalled and medium-sized but yet undescribed discinoid with a low conical ventral valve in the Acanthopyge Limestone. Fragments are similar to some Silurian thick-walled representatives of the genus [A. cocksi Mergl, 2006, A. bubovicensis (Mergl, 2001a)]. Fragments are distinct from Acrosaccus vertex Mergl \& Ferrová, 2008 reported from the Chýnice Limestone (Emsian) by the thick-walled shell and a narrow spindle-shaped pedicle track. Acrosaccus sp. from the Acanthopyge Limestone (Eifelian) (Mergl, 2008) also differs from our fragments due to its thin-walled shell.

Occurrence. - Suchomasty (Červený quarry), Acanthopyge Limestone, costatus Zone (zonal identification based on the occurrence of Polygnathus sp. aff. P. trigonicus reported by Klapper et al. 1978).

\section{Genus Chynithele Havlíček in Havlíček \& Vaněk, 1996}

Type species. - Chynithele ventricona Havlíček in Havlíček \& Vaněk, 1996; Zlíchov Formation, Emsian, Devonian; Prague Basin, the Czech Republic.

\section{Chynithele amoena Mergl, 2008}

Figure 7E

2008 Chynithele amoena sp. nov. - Mergl, pp. 289, 290, fig. 7.
Material. - One dorsal valve.

Remarks. - Mergl (2008) discussed the morphology of this species and the differences between $C$. amoena and $C$. ventricona. There is a gradual change in details of the dorsal valve rugellate ornamentation from Chynithele ventricona Havlíček in Havlíček \& Vaněk, 1996 (Chýnice Limestone, lower Emsian) to C. amoena (Acanthopyge Limestone, Eifelian). Our single specimen shows distant and less robust concentric rugellae, which justifies is attribution to C. amoena.

Occurrence. - Choteč (Na Škrábku quarry), Třebotov Limestone, serotinus Zone.

\section{Genus Lochkothele Havlíček \& Mergl, 1988}

Type species. - Discina intermedia Barrande, 1879; Lochkov Formation, Lochkovian, Devonian; Prague Basin, the Czech Republic.

\section{Lochkothele sp.}

Figure 7O-Q

Material. - Four fragments of ventral valves.

Description. - The shell outline is not well known, but judging from the fragments, it is subcircular to broadly oval, with the maximum width at about midlength of the shell. The ventral valve is low conical, with a distinct, slightly convex, and transversely oval larval shell that has a straight posterior edge. The pedicle track is a deeply incised, semicylindrical channel almost imperceptibly widening posteriorly with an acute triangular notch at the posterior end. Distinct,

Figure 7. A - Barrandeoglossa sp. Incomplete dorsal valve, exterior of SB6, Choteč (Na Škrábku quarry), Třebotov Limestone, lower Eifelian, partitus Zone. • B, C - Kosagittella pulsatilla Mergl, 2008. • B - incomplete ventral valve, exterior of SB7, Chýnice (Jelínek mill quarry), Třebotov Limestone, upper Emsian, serotinus Zone. • C - incomplete dorsal valve of SB8, Suchomasty (Červený quarry), Acanthopyge Limestone, Eifelian, costatus Zone (zone identification based on the occurrence of $P$. sp. aff. P. trigonicus Bischoff \& Ziegler, 1957 reported by Klapper et al. 1978). $\bullet$ D - detail of microornament of postlarval shell of SB9, Chýnice (Jelínek mill quarry), Choteč Limestone, Eifelian, costatus Zone. • E - Chynithele amoena Havlíček, 1996. Dorsal valve, exterior of SB10, Choteč (Na Škrábku quarry), Třebotov Limestone, upper Emsian, serotinus Zone. • F - Praeoehlertela sp., dorsal valve, exterior of SB11, Suchomasty (Červený quarry), Acanthopyge Limestone, Eifelian, costatus Zone (zone identification based on the occurrence of P. sp. aff. P. trigonicus Bischoff \& Ziegler, 1957 reported by Klapper et al. 1978). $-\mathrm{G}, \mathrm{K}-$ Paterula holynensis Mergl, 2001 , shell fragment of SB12


quarry), Acanthopyge Limestone, Eifelian, costatus Zone (zone identification based on the occurrence of $P$. sp. aff. P. trigonicus Bischoff \& Ziegler, 1957 reported by Klapper et al. 1978). • H - incomplete ventral valve, exterior of SB14. • I - incomplete ventral valve, exterior of SB13. - J, L-N - Opatrilkiella kobyla Mergl, 2008. • J - incomplete dorsal valve, exterior of SB16, Praha - Barrandov (road cut), uppermost Choteč Limestone, Eifelian, ?australis Zone (zone identification based on the occurrence of $P$. pseudofoliatus, for discussion see Berkyová 2009 ). $\bullet \mathrm{L}-$ dorsal valve, exterior of SB18, Chýnice (Jelínek mill quarry), Třebotov Limestone, upper Emsian, uppermost serotinus Zone. • M - ventral valve, exterior of SB17, Praha Barrandov (road cut), uppermost Třebotov Limestone, Eifelian, basal costatus Zone. • N - dorsal valve, exterior of SB19, Chýnice (Jelínek mill quarry), Třebotov Limestone, upper Emsian, serotinus Zone. • O-Q - Lochkothele sp. $\bullet$ O - incomplete ventral valve, exterior of SB20, Suchomasty (Červený quarry), basal Acanthopyge Limestone, Eifelian, partitus Zone. • P - incomplete ventral valve, exterior of SB21, Chýnice (Jelínek mill quarry), Třebotov Limestone, upper Emsian, serotinus Zone. - Q - incomplete ventral valve, exterior of SB22, Praha-Holyně (Prastav quarry), Třebotov Limestone, Eifelian, basal partitus Zone. Length of bars in $\mu \mathrm{m}$. 


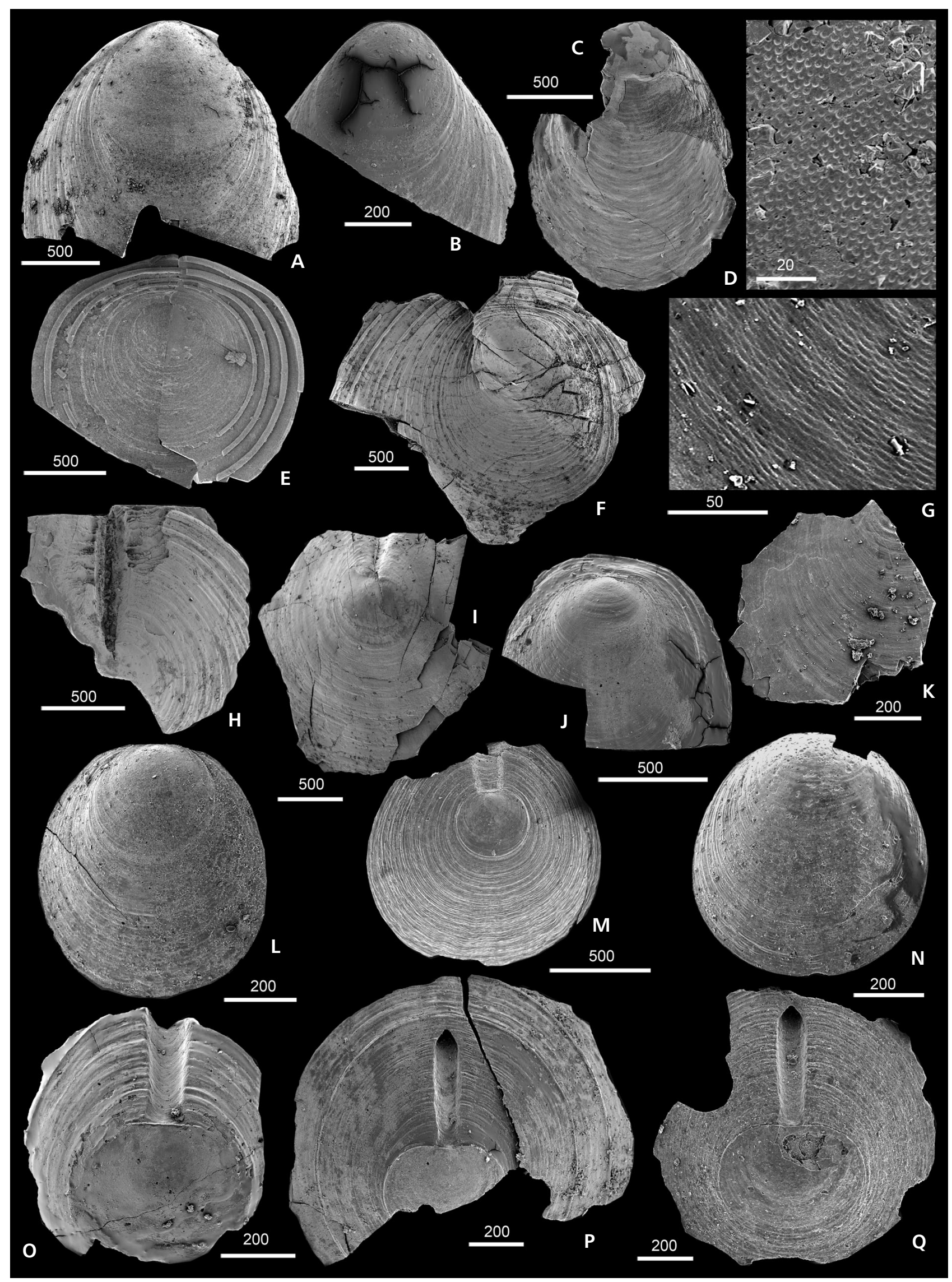


anteriorly convex growth lines cover the bottom of the pedicle track. Discrete listrial plates are absent. Ornamentation of the post-larval shell consists of fine concentric growth lines and fine rope-like rugellae arranged at broad intervals.

Remarks. - The unique shape of the pedicle track is the same as that observed by Mergl (2001a) in Lochkothele intermedia (Barrande, 1879) (Lochkovian, Lochkov Formation; Prague Basin) and Lochkothele sp. (Emsian, Chýnice Limestone, Prague Basin; Mergl \& Ferrová 2009). Weak rugellae on the surface of the post-larval shell are also consistent with the attribution of all three fragments to Lochkothele Havlíček \& Mergl, 1988, but their relationship to the type species is unclear.

Occurrence. - Choteč (Na Škrábku quarry), Třebotov Limestone, upper partitus Zone; Chýnice (Jelínek mill quarry), Třebotov Limestone, serotinus Zone; Praha - Holyně (Prastav quarry), Třebotov Limestone, basal partitus Zone; Suchomasty (Červený quarry), basal Acanthopyge Limestone, upper partitus Zone.

\section{Genus Opatrilkiella Mergl, 2001a}

Type species. - Opatrilkiella minuta Mergl, 2001a; Požáry Formation, Přídolí, Silurian; Prague Basin, the Czech Republic.

\section{Opatrilkiella kobyla Mergl, 2008}

Figure 7J, L-N

2001a Opatrilkiella(?) sp. B. - Mergl, p. 30, pl. 24, fig. 10.

2008 Opatrilkiella kobyla sp. nov. - Mergl, p. 290, figs $8,9$.

2009 Opatrilkiella kobyla Mergl, 2008. - Mergl \& Ferrová, p. 532 , figs 8,9 .

Material. - Six dorsal and three ventral valves, several small fragments.

Remarks. - The recently collected specimens from the Choteč Limestone are morphologically consistent with the shells previously collected in the Acanthopyge and Choteč limestones (Eifelian). The distinctive ornamentation of the post-larval shell consisting of wrinkled concentric lines that are interrupted by arrays of composite rheomorphic folds, and the remarkable variability in outline has also been observed in the present specimens.

Occurrence. - Choteč (Na Škrábku quarry), Choteč Limestone, costatus Zone; Praha -Barrandov (road cut), uppermost Třebotov and Choteč limestones, basal costatus-?australis Zone (the latter zonal identification based on the occurrence of $P$. pseudofoliatus); Praha- Holyně (Prastav quarry), Třebotov and Choteč limestones, partitus-costatus zones; Chýnice (Jelínek mill quarry), Třebotov Limestone, serotinus Zone.

\section{Genus Praeoehlertella Mergl, 2001a}

Type species. - Praeoehlertella umbrosa Mergl, 2001a; Praha Formation, Pragian, Devonian; Prague Basin, the Czech Republic.

\section{Praeoehlertella sp.}

Figure 7F

Material. - Two incomplete dorsal valves.

Description. - The valve is thick-walled, flat, with a gently convex submarginal apex. The outline is broadly oval, about $120 \%$ as long as wide, with maximum width at about the shell's midlength. The posterior margin is less rounded than the flanks. Ornamentation consists of distinct low concentric rugellae with sharp crests which are separated by flat wider interspaces. The rugellae slowly but constantly increase in size with shell growth.

Remarks. - The valve ornamentation is similar to that of the dorsal valve from the Acanthopyge Limestone (Eifelian) and referred to Orbiculoidea sp. by Mergl (2008). The only difference is the more elongate shell outline of the new specimen. The shell shape is also similar to Praeoehlertella sp. (Chýnice Limestone, Emsian; Prague Basin) (Mergl \& Ferrová 2009) but differs by the more irregular and compressed rugellate ornamentation.

Occurrence. - Karlštejn (U Němců section), Choteč Limestone, partitus Zone; Suchomasty (Červený quarry), basal Acanthopyge Limestone, partitus Zone.

Order Acrotretida Kuhn, 1949

Superfamily Acrotretoidea Schuchert, 1893

Family Biernatidae Holmer, 1989

\section{Genus Havlicekion Mergl, 2001a}

Type species. - Havlicekion splendidus Mergl, 2001a; Praha Formation, Pragian, Devonian; Prague Basin, the Czech Republic.

Havlicekion sp. aff. frydai Mergl \& Ferrová, 2009 Figure 8A-I, K

Material. - Three dorsal and five ventral valves. 
Description. - The shell is less than $1 \mathrm{~mm}$ wide in adults, thick-walled relative to size, with clearly unisulcate commissure.

The dorsal valve is transversely broadly oval, with a broad, weak and rapidly widening sulcus. The flanks are flat. The maximum width is situated slightly anterior to the midlength of the shell. The dorsal pseudointerarea is weakly apsacline, occupying about one-third of the valve's width, with small propareas and a broad, suboval and rather deep median groove. The visceral area is weakly defined. The triangular median septum is blade-like, occupying almost $90 \%$ of the valve's length. Its anterior base is more anterior than the tip of the lower rod. The upper rod is shorter, equally robust as the lower rod, occupying two-thirds of septal length. The tips of the rods are rounded. The base of the septum extends from a low median buttress. Cardinal muscle scars are large, oblique, widening anteriorly, with a surface moderately taller than the adjacent shell floor.

The ventral valve is highly conical, having catacline, narrowly triangular pseudointerarea with a narrow intertrough. The pseudointerarea bears coarse rope-like growth fila. Anterior and lateral slopes are gently convex. The ventral larval shell has a circular outline, having a circular pedicle opening that is posteroventrally directed. The short pedicle tube forms the highest point of the valve. The boundary of the larval shell is clearly defined and elevated above the surface of the post-larval shell.

Ornamentation of the larval shell consists of overlapping circular and lunate flat-based pits of uneven size. The pits are 2 to $5 \mu \mathrm{m}$ in diameter, with a dominance of the larger pits. Interspaces bear hemispherical pits of different sizes. The post-larval shell bears regularly arranged concentric rugellae increasing in size with growth. The rugellae are most prominent on the anteromedian slope, becoming less prominent laterally. Long, fine, and meandering rheomorphic radial grooves are present in the median sector of the valve. The microornamentation of the post-larval shell consists of fine concentric striation, with striae $2 \mu \mathrm{m}$ apart.

Remarks. - The new shells are very similar to the specimens described from the Chýnice Limestone (Emsian) by Mergl \& Ferrová (2009). There are the same features which are discernible in the typical specimens of $H$. frydai: the prominent concentric rugellae on the external surface, the short dorsally directed tongue-like projection on the dorsal edge of the ventral pseudointerarea, and the overlapping pits on the surface of the larval shell. However, a slight difference exists in the direction of the external pedicle opening and convexity of the ventral larval shell. In the specimens from the Chýnice Limestone, the pedicle foramen is directed more posteriorly than in the newly collected specimens. The foramen is at about the same height as the apex of the larval shell. However, the pedicle openings of specimens from the Třebotov and Choteč limestones are more ventrally directed and clearly form the apex of the larval shell. It is hard to evaluate the taxonomic importance of this difference because there are no studies of biernatid larval shell variability. Unfortunately, the new material is less numerous and represented mostly by small-sized shells. Thus, the specimens are provisionally referred to $H$. frydai although it is possible that the shells from the Třebotov and Choteč limestones represents a separate species derived from $H$. frydai.

Occurrence. - Choteč (Na Škrábku quarry), Třebotov and Choteč limestones, partitus-costatus Zone [the latter zone identification based on the occurrence of P. sp. aff. P. trigonicus and Nowakia (Dmitriella) sulcata sulcata Roemer, 1843]; Praha - Barrandov (road cut), uppermost Třebotov Limestone, basal costatus Zone.

\section{Havlicekion sp.}

Figure 8J, L-N

\section{Material. - Seven ventral valves.}

Description. - The ventral valve is acutely conical, with a straight, steeply inclined anterior slope. The ventral pseudointerarea is catacline, weakly depressed and has a narrow intertrough defined by inflections of the growth fila. The anterior edge of the intertrough is straight and transverse. The larval shell is highly conical having straight anterior and lateral slopes. The posterior slope is catacline. There is a weak concentric subperipheral depression flanking the margin of the larval shell. The external pedicle opening is circular, $30 \mu \mathrm{m}$ in diameter and directed ventrally.

The ornamentation of the mature shell consists of raised, uniformly sized concentric fila that are separated by interspaces of the same size and are interrupted and partitioned by long, straight rheomorphic radial lines on the anterior slope. The microornamentation of the larval shell consists of circular, often partially overlapping flat-bottomed pits of almost uniform size (ca $5 \mu \mathrm{m})$.

Remarks. - The specimens differ from some described species of Havlicekion by possessing less prominent ornamentation and an acutely conical ventral larval shell with a ventrally directed pedicle opening. However, these features indicate an affinity with Havlicekion holynensis Mergl, 2001a from the Kotýs Limestone (Lochkov Formation, Lochkovian) of the Prague Basin. This stratigraphically much older species also has a conical ventral larval shell and its mature shell ornamentation forms rather fine but distinct raised growth fila. 
Occurrence. - Choteč (Na Škrábku quarry), Třebotov and Choteč limestones, patulus-costatus zones.

\section{Genus Opsiconidion Ludvigsen, 1974}

Type species. - Opsiconidion arcticon Ludvigsen, 1974; Emsian, Devonian; Yukon, Canada.

\section{Opsiconidion decessus Mergl, 2001a}

Figure 9A-N

Material. - Almost fifty specimens (dorsal and ventral valves) in various degrees of preservation.

Remarks. - The new material comprises numerous but mostly fragmentary shells which have the typical features of the species: a tall, acutely conical ventral shell with weak growth lines, a weakly defined and narrow pseudointerarea (Fig. 9G), an acutely conical ventral larval shell with a ventrally directed apical pedicle opening (Fig. 9A, M), and a subpentagonal dorsal valve having a thin, tall and blade-like median septum with two rods (Fig. 9B, D). There is a minor difference in length and flattening of the upper rod between the original and new specimens (Mergl 2001a; pl. 31, figs 6, 7, 8, 16), but moderate variability in this feature is common even among shells from the same sample. Another distinct feature of this species is the rather uniform pitting of the larval shell (Fig. 9K, $\mathrm{M}, \mathrm{N}$ ). The large flat-bottomed pits are uniformly sized, circular, in contact with each other and in a honeycomblike arrangement. Some crosscutting of large pits occurs only along the anterior margin of the larval shell (Fig. 9N). Interspaces between the flat-bottomed pits are weakly elevated and bear much smaller hemispherical pits. This rather large biernatid was formerly known only from the Choteč and Acanthopyge limestones of the Choteč Formation (Mergl 2001a, 2008).

Occurrence. - Choteč (Na Škrábku quarry), Třebotov and Choteč limestones, partitus-costatus zones; Chýnice (Jelínek mill quarry), Třebotov and Choteč limestones, serotinus-kockelianus zones; Praha-Barrandov (road cut), uppermost Třebotov and basal Choteč limestones, basal costatus Zone; Praha - Holyně (Prastav quarry), Třebotov and Choteč limestones, partitus-costatus zones.

Superfamily Siphonotretoidea Kutorga, 1848

Family Siphonotretidae Kutorga, 1848

\section{Genus Orbaspina Valentine \& Brock, 2003}

Type species. - Orbaspina gelasinus Valentine \& Brock, 2003; Wenlock, Silurian; New South Wales, Australia.

\section{Orbaspina sp.}

Figure $10 \mathrm{~A}-\mathrm{C}$

Material. - Two incomplete dorsal valves.

Description. - Based on the two incomplete dorsal valves, the adult shells grew up to approximately $1 \mathrm{~mm}$ in length. The dorsal valve is subcircular, with a posteriorly pointed apex. The valve is moderately vaulted convexly both transversely and axially, with a flattened narrowly triangular median sector. The brephic shell is subcircular, $c a 180 \mu \mathrm{m}$ wide, axially depressed in its anterior half, and possesses a raised posterior lobe and a pair of lower anterolateral lobes. The margins of the shell are weakly defined. The mature shell bears concentric rows of asymmetrical pits, uniformly sized over the whole shell. The pits are 15 to $20 \mu \mathrm{m}$ wide, transversely elliptical and deepest in the posterior half. The dorsal valve interior has a short and deeply concave pseudointerarea.

Remarks. - The fragmentary preservation of the valves does not allow a comprehensive comparison with other Devonian siphonotretoids. The shells are most similar to $\mathrm{Or}$ baspina postera (Mergl, 2001b) described from the Praha Formation (Pragian) in the Prague Basin. The Pragian species differs from other species referred to Orbaspina (O. gelasinus Valentine \& Brock, 2003, O. chlupaci Mergl, 2003) by the absence of hollow spines. This feature has led Mergl (2001 a, 2001b) to the incorrect attribution of Orbaspina postera to the genus Dysoristus Popov \& Ushatinskaya, 1992 of the Dysoristidae Popov \& Ushatinskaya, 1992. However, the general morphology of Orbaspina postera and the newly collected shells from the Třebotov

Figure 8. A-I, K - Havlicekion sp. aff. frydai Mergl \& Ferrová, 2009. • A - dorsal valve, interior of SB23, Choteč (Na Škrábku quarry), Třebotov Limestone, Eifelian, partitus Zone. • B - dorsal valve, interior of SB24, Choteč (Na Škrábku quarry), Třebotov Limestone, Eifelian, partitus Zone. $\bullet$ C -dorsal valve, exterior of SB25, Choteč (Na Škrábku quarry), Choteč Limestone, Eifelian, costatus Zone (zonal identification based on the occurence of $P$. sp. aff. P. trigonicus Bischoff \& Ziegler, 1957). • D - dorsal valve, interior of SB26, Choteč (Na Škrábku quarry), Třebotov Limestone, Eifelian, partitus Zone. - E, H, I - ventral valve, exterior, detail of larval shell and pseudointerarea of SB27, Choteč (Na Škrábku quarry), Třebotov Limestone, Eifelian, partitus Zone. $\bullet \mathrm{F}, \mathrm{K}-$ ventral valve, exterior and interior of SB28, Praha - Barrandov (road-cut), uppermost Třebotov Limestone, Eifelian, basal costatus Zone. - G - dorsal valve, interior, lateral view of SB23, Choteč (Na Škrábku quarry), Třebotov Limestone, Eifelian, partitus Zone. • J, L-N - Havlicekion sp., Choteč (Na Škrábku quarry), Třebotov Limestone, Eifelian, partitus Zone. $\bullet J, N-$ ventral valve, detail of larval shell and exterior of SB29. $\bullet$ L, M - ventral valve, pseudointerarea and lateral view of SB30. Length of bars in $\mu \mathrm{m}$. 


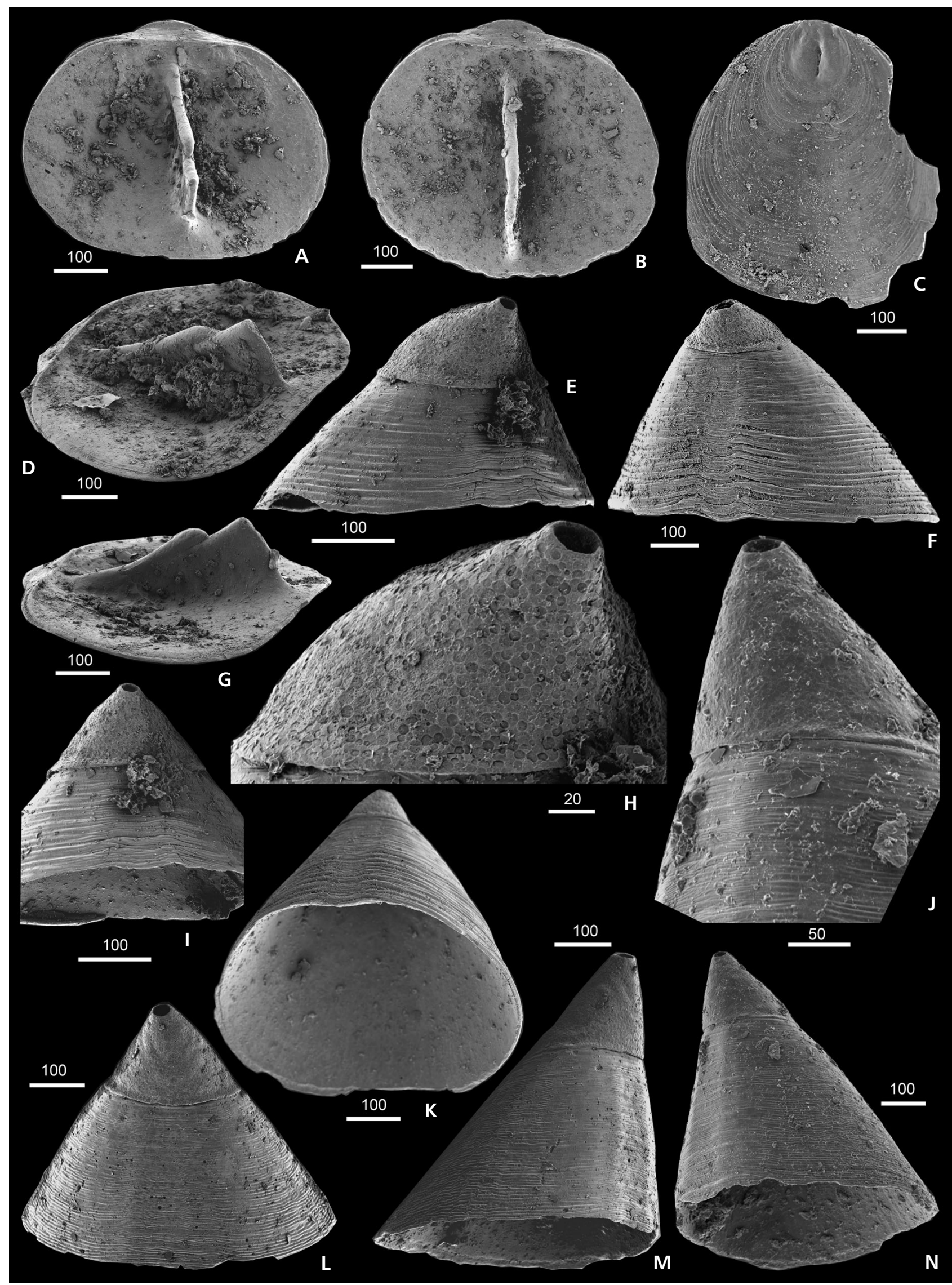


Limestone, especially their pitted surface, the flattened median sector, and the deeply concave dorsal pseudointerarea, are consistent with their assignment to the siphonotretids. The siphonotretid Schizambonine sp. B, described by Mergl (2001a) from the Třebotov Limestone of the Prastav Quarry (bed No. 5) in Praha-Holyně, lacks a clearly pitted surface and displays peripheral hollow tubes (Mergl 2001a; pl. 36, figs 11-14). These features differentiate Schizambonine sp. B from the newly sampled shells. It is likely that Schizambonine sp. B represents members of a different siphonotretine clade existing up to the earliest Middle Devonian.

Occurrence. - Chýnice (Jelínek mill quarry), Třebotov Limestone, lowermost Eifelian, lowermost partitus Zone.

\section{Discussion}

As Fig. 11 indicates, the brachiopod taxa were recovered mainly from autochthonous micritic limestones (Fig. 11A-C, F-I). The following taxa were recorded in both of the facies types, i.e. the micritic limestones and the grainstone facies (alochthonous calciturbidites): Havlicekion sp., Kosagittella pulsatilla, Opatrilkiella kobyla and Opsiconidion decessus, with Schizotreta sp. being recorded only in the grainstone facies. Occurrences of Havlicekion sp., Kosagittela pulsatila and Opatrilkiella kobyla in the grainstone facies were recorded only rarely. The most striking is the occurrence of the biernatid Opsiconidion decessus, which is common in the light bioturbated skeletal wackestones, dark burrowed lime-mudstones and wackestones, in peloidal packstones and also in crinoidal and peloidal grainstones. The obvious facies independence of this genus raises the question as to its mode of life.

\section{Opsiconidion shell morphology and mode of life}

Unlike the majority of acrotretoids, Opsiconidion has an almost smooth shell surface and a very narrow undepressed ventral pseudointerarea. The thin shell, absence of distinct growth lamellae, and a ventrally directed foramen piercing the top of an acutely conical larval shell are other typical features which distinguish the Opsiconidion shell. The almost regularly conical valve with a ventrally directed pedicle foramen is indicative of the ventral apex down attitude of Opsiconidion during life. The morphology would be different assuming that the shell faced towards the substrate by the ventral pseudointerarea; in such a case, the ventral pseudointerarea would be depressed and the pedicle foramen would be directed posteroventrally to posteriorly. There are many Cambrian and Ordovician acrotretides with such morphology: the genera Acrotreta, Dactylotreta, Hadrotretata, Polylasma, Sasyksoria, and Torynelasma are good examples. They have strongly depressed ventral pseudointerareas and their pedicle foramina are posteroventrally to posteriorly directed. The latter indicates that the pedicle served for adhesion to the substrate. The depressed ventral pseudointerarea indicates the preferred shell orientation during life. These acrotretoids probably selected epibenthic habitats on diverse firm or hard substrates. Sponges, conulariids, seaweeds or bioclasts have been documented or assumed as suitable substrates (Rowell \& Krause 1973, Holmer 1989, Holmer et al. 2005, Mergl 2002).

When judging the Opsiconidion mode of life, the rock type, from which the taxon has been recovered, should be taken into account. From the following sediment types Opsiconidion has also been collected: marls (Biernat 1984), argillaceous limestones and marlstones (Popov et al. 1994), black massive limestone (Valentine et al. 2006), fine sediments (oxygenated environment) (Botting 2002), dark and grey micritic limestones (Mergl 2001a), mudstones to siltstones (Cocks 1979) and dark gray to black argillaceous limestones (Ludvigsen 1974). Mergl (2001a, 2008) and Mergl \& Ferrová (2009) reported this genus also from grainstone and floatstone facies (Acanthopyge and Chýnice limestones, Prague Basin), however, only sporadically. Valentine et al. (2003) reported this genus from coarse-grained red limestone (shallow marine, moderate energy) and marly limestones. Judging from the published record regarding this genus, it appears reasonable to conclude that a muddy bottom was the original habitat for Opsiconidion. However, as mentioned above, Opsiconidion has been recovered from various facies types (Třebotov and Choteč limestones, Fig. 11). A similar distribution (occurrences in wackestones, lime-mudstones and grainstones) has been recorded in lower Devonian

Figure 9. A-N - Opsiconidion decessus Mergl, 2001. - A-D, F, G-H, L, M-N - Praha - Barrandov (road-cut), uppermost Třebotov Limestone, Eifelian, costatus Zone. $\bullet$ A - ventral valve, exterior of SB31. $\bullet$ B - dorsal valve, interior of SB32. $\bullet$ C - dorsal valve, exterior of SB33. $\bullet$ D - dorsal valve, interior of SB34. $\bullet \mathrm{F}$ - ventral valve, exterior of SB35.・G, M - ventral valve, pseudointerarea and detail of larval shell of SB36. $\bullet$ H, N - ventral valve, exterior and larval shell with pitting of SB37. $\bullet$ L - ventral valve, detail of pseudointerarea of SB38. E - dorsal valve, exterior of SB39. Chýnice (Jelínek mill quarry), Třebotov Limestone, upper Emsian, serotinus Zone. • I-dorsal valve, interior of SB40, Chýnice (Jelínek mill quarry), Třebotov Limestone, upper Emsian, serotinus Zone. $\bullet J$ - dorsal valve, exterior of SB41, Chýnice (Jelínek mill quarry), Choteč Limestone, Eifelian, costatus Zone. $\bullet$ K - dorsal valve, larval shell of SB42, Praha - Barrandov (road-cut), basal Choteč Limestone, costatus Zone. Length of bars in $\mu \mathrm{m}$. 







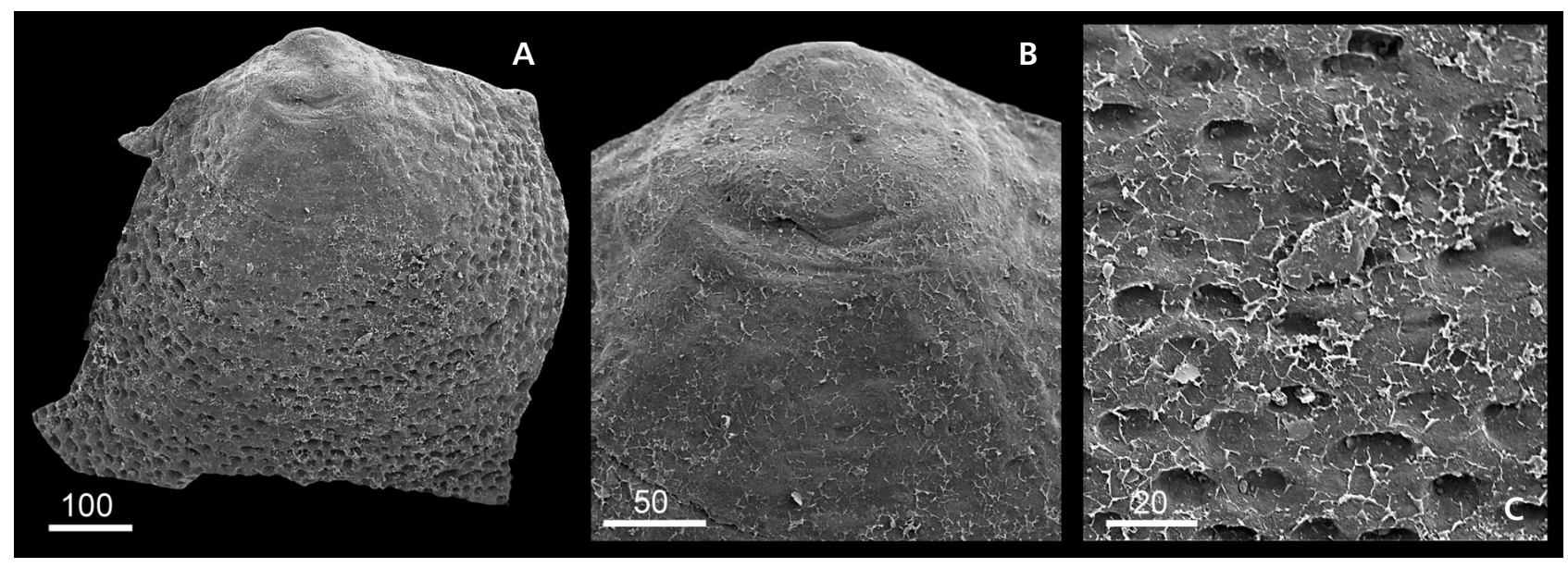

Figure 10. A-C - Orbaspina sp. Chýnice (Jelínek mill quarry), Třebotov Limestone, lowermost Eifelian, lowermost partitus Zone. • A-C - dorsal valve exterior, detail of the larval shell, and detail of pits of postlarval shell of SB43. Length of bars in $\mu \mathrm{m}$.

sections in the Prague Basin, e.g., U Topolů section and Černá rokle (Michael A. Murphy, personal communication). Similar facies independence of Opsiconidion and some other acrotretoids has been recorded in Argentina and the Canadian Arctic (Jen Duffy and Brian Chatterton, personal communication, manuscript in preparation). The grainstones of the Choteč Limestone represent calciturbidites, thus sediments transported from more shallow water environments down a slope. Opsiconidion occurs both in autochtonous (wackestones, lime-mudstones) and allochtonous facies (grainstones), which implies that the animal could have lived both on the muddy substrate in a deep, calm environment and on a coarse substrate in a shallow-water, moderately agitated environment. Another possible explanation exists, namely that Opsiconidion was epiplanktonic in its mode of life and thus independent on the lithofacial development.

\section{Possibility 1: muddy substrate as a life habitat for Opsiconidion}

A semi-infaunal mode of life for Opsiconidion in a calmer, deeper environment was suggested by Mergl (2001a, 2008). The shell morphology of Opsiconidion, with a tall thin conical ventral valve and a tall internal dorsal septum, seems an advantageous morphology for a sedentary habit on a soft substrate. Deep burrowing of the conical ventral valve could speculatively stabilize the shell in soft mud, having only the narrow commissural periphery of the shell elevated above the sediment/water interface. The pedicle of Opsiconidion could give significant support to the stability of an animal wedged between much smaller sediment particles. The remarkably extended posterior of micromorphic Devonian and Carboniferous brachiopods of the Lambdarinidae, Brunton \& Champion, 1974, may repre- sent an adaptation to a similar habitat in a low-energy soft substrate. Labdarina Brunton \& Champion, 1974 and other cardiarinides are known from well-bedded micritic limestones (Bassett \& Bryant 1993). The larva of Opsiconidion which possessed a conical shell, may have settled on any small grain on the sea bottom (e.g. a bioclast). Subsequent growth of the postlarval conical ventral valve compensated for the deposition of mud around and above this grain. In some samples of Silurian limestones in the Czech Republic, the juvenile shells of Opsiconidion are substantially more frequent than the adult shells. This indicates a high juvenile mortality of the local population. There can be various reasons for this juvenile mass mortality; we assume that such juvenile mortality could be explained by the inability to compensate for a rapid intake of mud.

The highly conical ventral valve of Opsiconidion also provided enough internal space for the effective functioning of the lophophore. A narrow slot opened between the almost buried conical valve and lid-like dorsal valve, the tall dorsal median septum separated the inhalant and exhalant currents, which created an effective adaptation to the life on muddy substrates. The filtration of oxygen-depleted water just above such a muddy bottom could have been a rather effective mode of life. A permanently growing bacterial mass in organic detritus-rich and oxygen-depleted near-bottom waters might have been the main food source of the Opsiconidion animal (see overview, e.g., in Carney 1981, Osborne 2000). The higher risk of eradication of local populations by minor fluctuations in environmental factors was compensated for by a short life span. This argues for the successful R-strategy of Opsiconidion. The miniaturization of body size of the biernatids could represent an adaptation to life on an oxygen deficient bottom with a greater supply of organic detritus and nannoplankton (compare e.g., with Jensen 1987, Soetaert et al. 2002). 


\section{Possibility 2: interstitial mode of life of Opsiconidion}

Cocks (1979) and Bassett (1984) suggested that Opsiconidion could have lived interstitially. The size of Opsiconidion is comparable with the Recent Gwynia capsula (Jeffreys, 1859), the micromorphic terebratellacean that represents one of the rare cases of brachiopods living interstitially in marine sands (Swedmark 1971, Logan et al. 1997). This species adheres to sand grains on which the larvae settle.

Considering what has been published previously (Mergl 2001a, 2008; Mergl \& Ferrová 2009), the biernatid Havlicekion could be a candidate for such an interstitial mode of life. It has a relatively low-conical, moderately thick ventral valve with a weakly depressed ventral pseudointerarea. Its shell surface is covered by fine but well developed concentric fila which strengthen the shell wall. Its shells are numerous in coarse-grained crinoidal limestones of the Kotýs, Chýnice and Suchomasty limestones in the Prague Basin. The attitude of Havlicekion, with the ventral apex down, was supported by fixation of the pedicle to a nearby grain. The pedicle was certainly a narrow cylinder near the apex but most likely had a small adhesive bulb or disk at the distal end. The length and the tubular form of an acrotretoid pedicle can be inferred from rare but preserved examples of tubular extensions of the larval shell (Bassett et al. 1999; Fig. 9-4). The raised fila on the shell surface enhance the resistance against shell breakage and increase the stability of a shell wedged between bioclasts.

As mentioned above, the morphology of Opsiconidion is different. Its ventral valve is a very tall, almost symmetrical cone having a subcircular commissural outline. The ventral pseudointerarea is very narrow and weakly depressed. The shell wall is thin, certainly more fragile than that of Havlicekion, externally almost smooth having delicate rhizomorphic folds but lacking coarser growth lines or lamellae. The foramen is small, circular, apical, piercing the top of the acutely conical larval shell. Shell morphology and distributional differences indicate different modes of life and environmental requirements of Opsiconidion and Havlicekion. These reasons argue against an interstitial habit of Opsiconidion in lime mud and, at least partially, against an interstitial habit in calcarenites.

\section{Possibility 3: epiplantkonic mode of life of Opsiconidion}

The presence of minute lingulate brachiopods in black graptolitic shales lead, e.g., Barron \& Ettensohn (1981), Ruedemann (1935), Schuchert (1911) and Williams \& Lockley (1983) to the conclusion that certain phosphatic

\begin{tabular}{|c|c|c|c|c|c|c|c|c|c|}
\hline brachiopod species & 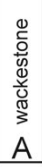 & 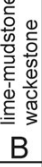 & 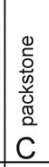 &  & 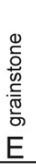 & 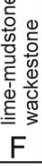 & 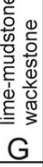 & 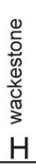 & 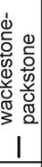 \\
\hline Havlicekion sp. & $x$ & & & $x$ & & & & $x$ & \\
\hline Havlicekion frydai & $x$ & & & & & & & $x$ & \\
\hline Kosagittella pulsatilla & $x$ & & & & $x$ & & & $\mathrm{x}$ & $x$ \\
\hline Opsiconidion decessus & $x$ & $\mathrm{x}$ & $x$ & $x$ & $x$ & $x$ & & $x$ & \\
\hline Lochkothele sp. & $x$ & & $x$ & & & & & & \\
\hline Prastavia sp. & $x$ & & & & & & & & \\
\hline Opatrilkiella kobyla & $x$ & & $x$ & $x$ & & & & $x$ & \\
\hline ?Prastavia sp. & $x$ & & & & & & & & \\
\hline Schizotreta sp. & & & & $x$ & & & & & \\
\hline Acrosaccus sp. & & & & & & & & & $x$ \\
\hline Praeoehlertella sp. & & & & & & & $x$ & & $x$ \\
\hline Opatrilkiella sp. & & & & & & & $x$ & & \\
\hline Orbiculoidea sp. & & & & & & & & & $x$ \\
\hline
\end{tabular}

Figure 11. Distribution of the brachiopod taxa versus diverse types of limestone. A - bioturbated skeletal wackestone, Třebotov Limestone; B - burrowed lime-mudstone and wackestone, Třebotov Limestone; C - peloidal packstone with prasinophytes, Třebotov Limestone; D - graded peloidal grainstone with crinoid ossicles, Choteč Limestone; E - fine-grained, laminated peloidal grainstone, Choteč Limestone; F - dark, micritic limestone with chert, Choteč Limestone; $\mathrm{G}$ - dark micritic limestone with not abundant prasinophytes, Choteč Limestone; H - light gray, burrowed-bioturbated skeletal wackestone, Choteč Limestone; I - crinoidal wacke-packstone with peloids, Acanthopyge Limestone.

brachiopods might have been adapted to an epiplanktonic mode of life. Similarly Bednarczyk \& Biernat (1978) and Rowell \& Krause (1973) regarded the possibility of an epiplanktonic mode of life in certain acrotretoids as probable. Floating or attached seaweeds have been repeatedly proposed as a possible host for the brachiopods, however, without direct evidence: no acrotretoid brachiopods attached to algae have yet been reported. Havlíček et al. (1993) described various brachiopods (lingulids, strophomenids and orthids) in association with Krejciella algae in the Ordovician of the Prague Basin and suggested an epiplanktonic mode of life for these brachiopods. Similarly, Williams \& Lockley (1983) reported one specimen of obolid brachiopod associated with an algal strand. For a critical overview on the epiplanktonic mode of life of certain brachiopods see, e.g., Holmer (1989).

The adaptations of Opsiconidion such as a probably short-life span, a thin shell, an apical, ventrally directed foramen as well as its micromorphic size could represent adaptations to an epiplanktonic mode of life. Floating seaweeds similar to Sargassum might have served as potential hosts for Opsiconidion in the Prague Basin, although it is rather speculative, as remains of neither seaweed with Opsiconidion nor without have been recorded thus far. In recent seas, seaweeds and sea-grass are common substrates for various organisms, such as, e.g., bryozoans, sponges, 
hydrozoans, barnacles, byssate bivalves, echinoderms (e.g., Pinet 2009). These organisms are attached by means of encrustation, cementation, fleshy stalk, byssus or other alternative. Opsiconidion would have to have been attached only by means of its thin pedicle (judging from the pedicle foramen size). The question arises whether the symmetrically conical shape of its thin-walled shell was the appropriate morphology for such a habitat. A somewhat similar morphology exists in extant stalked barnacles (e.g., Lepas) having fleshy stalks, but they have a much bigger body and their "shell" consists of small sclerites covering the soft body.

As an epiplanktonic animal, Opsiconidion should occur independent of facies. As implied from Fig. 11, this condition is obviously met in the Lower-Middle Devonian strata of the Prague Basin. It is noteworthy, however, that Opsiconidion is absent from the Silurian and Lower Devonian graptolitic shales of the Prague Basin, from which rare clusters of floating algae are known (Bouček 1941).

We cannot rule out that the distribution of Opsiconidion over a wide diversity of lithofacies was due to high environmental tolerance and the ability to find appropriate microhabitats in diverse environments including deep and oxygen deficient bottoms. It should also be kept in mind that this genus has been recorded especially in micritic facies not only in the Prague Basin but also elsewhere (see above).

Taken all together, there is no compelling evidence for an epiplanktic or a benthic (semi-infaunal) mode of life in Opsiconidion. A detailed study focusing on the distribution of Opsiconidion worldwide across more stratigraphic horizons might shed more light on this question. Because such data is so far lacking, we leave the question as to the mode of life of Opsiconidion open, although we regard the possibility of an epiplanktonic mode of life as attractive, especially considering its lithofacies independence and its micromorphic size. The attention should be directed, e.g., to fossilized Silurian and Devonian algal rests, as to potential hosts of micromorphic brachiopods. Up to now, lingulate shells have been collected only from residues of acid-dissolved limestone and this technique largely obscures their paleoecology.

\section{Conclusions}

Lingulate brachiopods of the Třebotov and Choteč limestones and their equivalents (Emsian-Eifelian, Lower-Middle Devonian, serotinus-kockelianus zones) were the subject of our study. Twelve species from the following genera have been found in these strata: Barrandeoglossa, Kosagitella, Paterula, Acrosaccus, Chynithele, Lochkothele, Opatrilkiella, Praeoehlertella, Havlicekion, Opsiconidion and Orbaspina.
These ligulate brachiopods do not display any significant change in taxonomic composition and diversity neither around the Emsian/Eifelian boundary nor around the Basal Choteč Event (Middle Devonian, Eifelian, costatus Zone) and thus confirms the general uniformity of lingulate faunas in the Lower and early Middle Devonian.

Lithofacies distribution and ecology of these lingulate brachiopods has been discussed, with the emphasis on Opsiconidion decessus, which was recorded in various facies types. We left the question as to Opsiconidion mode of life open, although its facies-independent occurrences support an epiplantkonic mode of life.

\section{Acknowledgements}

This research was supported by a grant from the Grant Agency of the Czech Republic GAČR 205/07/0466: Origin and evolution of the discinoid brachiopods in the Palaeozoic, the Czech-American Cooperation Program (Kontakt ME08011) and grants from the Czech Geological Survey (333300, 323000, 334000). This is our contribution to IGCP 596. S.V. was formerly known as Stana Berkyová. The paper benefited from the meticulous reviews of James L. Valentine (Macquarie University, Australia), Christian Klug (University of Zurich, Switzerland) and an anonymous reviewer, which significantly improved the manuscript. Michael A. Murphy (University of California, US) and Brian Chatterton (University of Alberta, Canada) are also thanked for fruitful discussions on the mode of life of Opsiconidion.

\section{References}

BARRANDE, J. 1879. Systême silurien du centre de la Bohême. Ière partie. Recherches paléontologiques. Vol. 5. Classe des Mollusques. Ordre des Brachiopodes. 226 pp. Prague \& Paris.

Barron, L.S. \& Ettensohn, F.R. 1981. Paleoecology of the Devonian-Mississippian black-shale sequence in eastern Kentucky with an atlas of some common fossils. 75 pp. Department of Geology, University of Kentucky, Kentucky Research Group.

BASSETt, M.G. 1984. Life strategies of Silurian brachiopods. Special Papers in Palaeontology 32, 237-263.

BassetT, M.G. \& Bryant, C. 1993. The micromorphic rhynchonelloidean brachiopod lamdarina from the type Dinantian. Journal of Palaeontology 67(4), 518-527.

Bassett, M.G., Popov, L.E. \& Holmer, L.E. 1999. Organophosphatic brachiopods: patterns of biodiversification and extinction in the early Palaeozoic. Geobios 32(1), 145-163. DOI 10.1016/S0016-6995(99)80026-6

BednARCZyK, W. \& Biernat, G. 1978. Inarticulate brachiopods from the Lower Ordovician of the Holy Cross Mountains, Poland. Acta Palaeontological Polonica 23(3), 293-316.

BerkyovÁ, S. 2009. Lower-Middle Devonian (upper EmsianEifelian, serotinus-kockelianus zones) conodont faunas from the Prague Basin, the Czech Republic. Bulletin of Geosciences 84(4), 667-686. 
BerkyovÁ, S. \& Munnecke, A. 2010. "Calcispheres" as a source of lime mud and peloids - evidence from the early Middle Devonian of the Prague Basin, the Czech Republic. Bulletin of Geosciences 85(4), 585-602.

BiernAt, G. 1984. Silurian inarticulate brachiopods from Poland. Acta Palaeontologica Polonica 29(1-2), 91-103.

Bischoff, G. \& Ziegler, W. 1957. Die Conodontenchronologie des Mitteldevons und des tiefsten Oberdevons. Abhandlungen des Hessischen Landesamtes für Bodenforschung 22, 1-136.

BotTing, J.P. 2002. The role of pyroclastic volcanisms in Ordovician diversification, 99-113. In CRAME, J.A \& OwEN, A.W. (eds) Paleobiogeography and biodiversity change: the Ordovician and Mesozoic-Cenozoic radiations. Geological Society of London, Special Publications 194.

BouČEK, B. 1941. O novém odkryvu siluru u Loděnic. Zprávy Geologického ústavu pro Čechy a Moravu 17, 165-172.

Brunton, C.H.C. \& Champion, C. 1974. A Lower Carboniferous brachiopod fauna from the Manifold Valley, Staffordshire. Palaeontology 17, 811-840.

CARNEY, R.S. 1981. Nutrients, 136-142. In Boucot, A.J. (ed.) Principles of benthic marine paleocology. Academic Press, New York.

CHLuPÁČ, I. 1957. Faciální vývoj a biostratigrafie středočeského spodního devonu. Sborník Ústředního ústavu geologického, Oddíl geologický 23, 369-485.

CHLupÁč, I. 1977. The phacopid trilobites of the Silurian and Devonian of Czechoslovakia. Rozpravy Ústředního ústavu geologického 43, 1-172.

Chlupáč, I. 1983. Trilobite assemblages in the Devonian of the Barrandian area and their relations to palaeoenvironments. Geologica et Palaentologica 17, 43-73.

Chlupéč, I. \& KuKal, Z. 1986. Reflection of possible global Devonian events in the Barrandian area, C.S.S.R. Lecture Note in Earth Sciences, 169-179.

Chlupáč, I. \& Kukal, Z. 1988. Possible global events and the stratigraphy of the Palaeozoic of the Barrandian (CambrianMiddle Devonian, Czechoslovakia). Sborník geologických věd, Geologie 43, 83-146.

Chlupáč, I., Lukeš, P. \& Zikmundová, J. 1979. The Lower-Middle Devonian boundary beds in the Barrandian area, Czechoslovakia. Geologica et Palaeontologica 13, 125-156.

Cocks, L.R.M. 1979. New acrotretacean brachiopods from the Palaeozoic of Britain and Austria. Palaeontology 22(1), 93-100.

Cooper, G.A. 1956. Chazyan and related brachiopods. Smithsonian Miscellaneous Collection 127, 1-1245.

Elrick, M., Berkyová, S., Klapper, G., Sharp, Z., JoAchimski, M. \& FRÝDA, J. 2009. Stratigraphic and oxygen isotope evidence for My-scale glaciation driving eustasy in the EarlyMiddle Devonian greenhouse world. Palaeogeography, Palaeoclimatology, Palaeoecology 276, 170-181.

DOI 10.1016/j.palaeo.2009.03.008

GRAY, J.E. 1840. Synopsis of the contents of the British Museum, $42^{\text {th }}$ edition. $370 \mathrm{pp}$. British Museum, London.

HavlíčEK, V. \& KuKal, Z. 1990. Sedimentology, benthic communities, and brachiopods in the Suchomasty (Dalejan) and Acanthopyge (Eifelian) Limestones of the Koněprusy area (Czechoslovakia). Sborník geologických věd, Paleontologie 31, 105-205.
HavlíčeK, V. \& Mergl, M. 1988. Two new discinid genera (Brachiopoda) from the Silurian and Devonian of the Prague Basin, Czechoslovakia. Věstník Českého geologického ústavu 63, 169-172.

HAVLÍČEK, V. \& VANĚK, J. 1996. Brachiopods and trilobites in the Chýnice Limestone (Emsian) at Bubovice (Čeřinka hillside; Prague Basin). Palaeontologica Bohemiae 2, 1-16.

Holmer, L.E. 1989. Middle Ordovician phosphatic inarticulate brachiopods from Västergötland and Dalarna, Sweden. Fossils and Strata 26, 1-172.

Holmer, L.E., Popov, L.E., Streng, M. \& Miller, J.F. 2005. Lower Ordovician (Tremadocian) lingulate brachiopods from the House and Fillmore formations, Ibex area, Western Utah, USA. Journal of Paleontology 79(5), 884-906.

DOI 10.1666/0022-3360(2005)079[0884:LOTLBF]2.0.CO;2

JEFFREYS, J.G. 1859. Gleanings in British conchology. Annals and Magazine of Natural History (series 3) 3, 30-43.

JENSEN, P 1987. Differences in microhabitat, abundance and body size between oxybiotic and thiobiotic free-living marine nematodes. Oecologia 71, 564-567.

KING, W. 1846. Remarks on certain genera belonging to the class Palliobranchiata. Annals and Magazine of Natural History (series 1) 18, 26-42.

KLAPPER, G. 1977. Lower-Middle Devonian boundary conodont sequence in the Barrandian area of Czechoslovakia. Casopis pro mineralogii a geologii 22(4), 401-410.

Klapper, G., Ziegler, W. \& MashKova, T.V. 1978. Conodonts and correlation of Lower-Middle Devonian boundary beds in the Barrandian area of Czechoslovakia. Geologica et Palaeontologica 12, 103-116.

KoptíkovÁ, L. 2010. Precise position of the Basal Choteč event and evolution of sedimentary environments near the Lower-Middle Devonian boundary: The magnetic susceptibility, gamma-ray spectrometric, lithological, and geochemical record of the Prague Synform (Czech Republic). Palaeogeography, Palaeoclimatology, Palaeoecology 304(1-2), 96-112. DOI 10.1016/j.palaeo.2010.10.011

Kunn, O. 1949. Lehrbuch der Paläozoologie. 326 pp. Schweizerbart, Stuttgart.

Kutorga, S.S. 1848. Ueber die Brachiopoden-familie der Siphonotretaceae. Russisch-Kaiserliche Mineralogische Gesellschaft zu St. Petersbourg, Verhandlungen 1847, 250-286.

Logan, A., MacKinnon, D.I. \& Phorson, J.E. 1997. Morphology, distribution, life habits and phylogenetic affinities of the recent brachiopod Gwynia capsula (Jeffreys). Marine Ecology 18(3), 239-252. DOI 10.1111/j.1439-0485.1997.tb00440.x

Ludvigsen, R. 1974. A new Devonian acrotretid (Brachiopoda, Inarticulata) with unique protegular ultrastructure. Neues Jahrbuch für Geologie und Paläontologie, Monatshefte 3, 133-148.

MENKE, C.T. 1828. Synopsis methodica molluscorum generum omnium et specierum earum quae in Museo Menkeano adservantur. 91 pp. G. Uslar, Pyrmonti.

Mergl, M. 2001a. Lingulate brachiopods of the Silurian and Devonian of the Barrandian. Acta Musei nationalis Pragae, Series $B$ - historia naturalis 57, 1-49.

Mergl, M. 2001b. Extinction of some lingulate brachiopod families: new stratigraphical data from Silurian and Devonian from Bohemia, 345-351. In Brunton, C.H.C., Cocks, L.R.M. \& 
Long, S. Brachiopods past and present. Systematic Association Special Volume 63.

Mergl, M. 2002. Linguliformean and craniiformean brachiopods of the Ordovician (Třenice to Dobrotivá Formations) of the Barrandian, Bohemia. Acta Musei Nationalis Pragae, Series $B$ - historia naturalis 58, 1-82.

Mergl, M. 2003. Orbaspina chlupaci sp. nov., a new siphonotretid brachiopod from the Silurian of the Barrandian area, Bohemia. Bulletin of Geosciences 78(4), 419-421.

Mergl, M. 2006. A review of Silurian discinoid brachiopods from historical British localities. Bulletin of Geosciences 81(4), 215-236. DOI 10.3140/bull.geosci.2006.04.215

Mergl, M. 2008. Lingulate brachiopods from the Acanthopyge Limestone (Eifelian) of the Barrandian, Czech, Republic. Bulletin of Geosciences 83(3), 281-298. DOI 10.3140/bull.geosci.2008.03.281

Mergl, M. \& Ferrová, L. 2009. Lingulate brachiopods from the Chýnice Limestone (upper Emsian, Barrandian; Czech Republic). Bulletin of Geosciences 84(3), 525-546. DOI 10.3140/bull.geosci.1143

OsBorne, P.L. 2000. Tropical ecosystems and ecological concepts. 464 pp. Cambridge University Press, Cambridge.

PINET, P. 2009. Invitation to oceanography. 576 pp. Jones \& Bartlett Learning, Burlington.

Popov, L.J. \& Ushatinskaya, G.T. 1992. Lingulidy, proizkhozhdenie discinid, sistematika vysokikh taksonov, 59-67. In Repina, L.N. \& Rozanov, A.Y. (eds) Drevneishiie brachiopody territorii Severnoi Evrazii. Obedinennyi institut geologii, geofyziki i mineralogii, SO RAN, Novosibirsk.

Popov, L.E., NõlvaK, J. \& HolmER, L.E. 1994. Late Ordovician lingulate brachiopods from Estonia. Palaeontology 37, $627-650$.

RoEmer, F.A. 1843. Die Versteinerungen des Harzgebirges. 40 pp. Hahn, Hannover.

Rowell, A.J. \& Krause, F.F. 1973. Habitat diversity in the Acrotretacea (Brachiopoda, inarticulata). Journal of Paleontology 47, 791-800.

RuEdemann, R. 1935. Ecology of black mud shales of eastern New York. Journal of Paleontology 9(1), 79-91.

Schuchert, C. 1893. Classification of the Brachiopoda. American Geologist 11, 141-167.

SCHUCHERT, C. 1911. Paleogeographic and geologic significance of recent brachiopods. Bulletin of the Geological Society of America 22, 258-275.
Soetart, K., Muthumbi, A. \& Heip, C. 2002. Size and shape of ocean margin nematodes: morphological diversity and depth-related patterns. Marine Ecology Progress Series 242, 179-193. DOI 10.3354/meps242179

Swedmark, B. 1971. A review of Gastropoda, Brachiopoda, and Echinodermata. Smithsonian Contribution to Zoology 76, $41-45$.

Svoboda, J. \& PrantL, F. 1947. O stratigrafii a tektonice staršího paleozoika v okolí Třebotova. Sborník Státního geologického ústavu Československé republiky 15, 1-39.

VALENTine, J. \& BRock, G.A. 2003. A new siphonotretid brachiopod from the Silurian of Central-Western New South Wales, Australia. Records of the Australian Museum 55(2), 231-244. DOI 10.3853/j.0067-1975.55.2003.1378

Valentine, J.L., Cole, D.J. \& Simpson, A.J. 2006. Silurian linguliformean brachiopods and conodonts from the Cobra Formation, southeastern New South Wales, Australia. Proceedings of the Linnean Society of New South Wales 111, 199-234.

Valentine, J., Brock, G.A. \& Molloy, P.D. 2003. Linguliformean brachiopod faunal turnover across the Irevikeven Event (Silurian) at Boree Creek, central-western New South Wales, Australia. Courier Forschungsinstitute Senckenberg 242, 301-327.

VodrážKová, S., Frýda, J., Suttner, T.J., Koptíková, L. \& TONAROVÁ, P. accepted for publication. Environmental changes close to the Lower-Middle Devonian boundary, the Basal Choteč Event in the Prague Basin (Czech Republic). Facies.

WaAgen, W. 1885. Salt Range fossils I. Productus-Limestone fossils, Brachiopoda. Memoirs of the Geological Survey of India, Palaeontologica Indica (series 13) 4(5), 729-770.

WILLARD, B. 1928. The brachiopods of the Ottosee and Holston formations of Tennessee and Virginia. Bulletin of the Harvard Museum of Comparative Zoology 68, 255-292.

Williams, H. \& Lockley, M.G. 1983. Ordovician inarticulate brachiopods from graptolitic shales at Dob's Linn, Scotland; their morphology and significance. Journal of Paleontology 57(2), 391-400.

WitTEKINDT, H. 1966. Zur Conodontenchronologie des Mitteldevons. Fortschritte in der Geologie von Rheinland und Westfalen 9, 621-646 [date of imprint 1965].

ZuskovÁ, J. 1991. Conodont faunas from the Lower/Middle Devonian section in Praha-Barrandov. Věstník Ústředního ústavu geologického 66(2), 107-112. 